\title{
Assessing Ecosystem Services Supplied by Agroecosystems in Mediterranean Europe: A Literature Review
}

\author{
Mario V. Balzan ${ }^{1, *(D)}$, Renata Sadula ${ }^{1}$ (D) and Laura Scalvenzi ${ }^{1,2}$ \\ 1 Institute of Applied Sciences, Malta College of Arts, Science and Technology, Triq Kordin, \\ PLA9032 Paola, Malta; Renata.Mikalauskiene@mcast.edu.mt (R.S.); lscalvenzi@uea.edu.ec (L.S.) \\ 2 Department of Earth Science, Agroindustrial Engineering, Universidad Estatal Amazonica, \\ Via Puyo-Tena km 2 1/2 paso lateral, Puyo EC160150, Ecuador \\ * Correspondence: mario.balzan@mcast.edu.mt
}

Received: 28 May 2020; Accepted: 16 July 2020; Published: 27 July 2020

\begin{abstract}
Agricultural landscapes in the Mediterranean region may be considered as social-ecological systems that are important for biodiversity conservation whilst contributing to a wide range of ecosystem services. This literature review aims to identify the current state and biases of ecosystem service assessment in agroecosystems within the Mediterranean region, evaluate pressures impacting on agroecosystems and their services, and practices that promote ecosystem service synergies in Mediterranean agroecosystems. A total of 41 papers were selected for analysis from a set of 573 potentially relevant papers. Most of the selected papers focused on supporting, regulating and provisioning services, and mostly assessed ecosystem structure or services in the European Mediterranean context. Literature about benefits and values ascribed to by communities and stakeholders remain limited. Results presented here support the notion of multifunctional Mediterranean agroecosystems and multiple synergies were recorded in this review. Publications dealing with pressures that related to agricultural practices and demographic changes were in the majority and impact on different cropping systems. This review highlights the need to carry out integrated ecosystem service assessments that consider the multiple benefits derived from agroecosystems and which may be used to identify management practices that lead to the improvement of ecosystem services capacities and flows.
\end{abstract}

Keywords: agriculture; biodiversity; agri-environment; pollination; pest control; food; climate; erosion; freshwater; soil fertility

\section{Introduction}

The Mediterranean region's agricultural landscapes are characterised by a prolonged human influence that has played a significant role in ensuring food security and in maintaining the region's rich biodiversity [1,2] and wide range of ecosystem services [3,4]. For more than 10,000 years, Mediterranean societies have used natural ecosystems and created cultural landscapes, which may be considered as highly co-evolved social-ecological systems.

The complexity of these multi-layered interactions in social-ecological systems is poorly understood, making it difficult to predict how ecosystem processes will respond to local and global drivers [5]. Sources of complexity in Mediterranean social-ecological systems include the relationship between historical human activities and the spatio-temporal variability of biodiversity and ecosystem processes, which lead to seasonal and long-term variations in ecosystem services [3] and which are continuously impacted by drivers and pressures which, often, act synergistically on ecosystems [6], and which can threaten future ecosystem service supply in the region [7]. 
Climate change, and regional and local drivers, including population growth, urbanisation and changes in agricultural practices, have been shown to impact on the Mediterranean region social-ecological systems, of which impacts include the reduction in crop provisioning services and biodiversity through the loss of extensive cultivation in agricultural landscapes, and the reduction in the capacity to provide cultural ecosystem services [8-10]. However, substantial variation in ecosystem services trends would be expected given the highly diverse nature of the region and varying landscape dynamics associated with different regions and landscape types [11].

The Mediterranean region's agricultural landscapes have been extensively studied for their ability to supply provisioning ecosystem services but literature about the contribution to regulation and cultural services remains limited and there is a lack of integrated approaches that consider biophysical, sociocultural and economic approaches to ecosystem service assessment [12]. However, recent literature provides evidence of the multifunctional nature of agricultural landscapes, which contribute to ecosystem services supplies and flows across rural-urban gradients $[13,14]$. These services are mediated by the agricultural practices, and some services may be negatively associated with the intensity of agricultural management, indicating a potential ecosystem service trade-off between food provisioning services and other ecosystem services [15]. Nevertheless, literature about the structural and functional characteristics of ecosystems that are necessary for the supply of ecosystem services remains limited. A more comprehensive understanding of the linkage between agrobiodiversity and ecosystem services is essential to predict how agricultural management, and other drivers, affect species and functional characteristics of ecosystems and the ecosystem services these underpin $[3,12,16]$.

Within this context, this study reviews recent literature on agroecosystem services in the Mediterranean region in order to (1) identify the main ecosystem services that have been studied in Mediterranean agroecosystems, (2) evaluate biases in the focus of literature on agroecosystem services, (3) evaluate potential pressures impacting on agroecosystems and ecosystem services and (4) identify practices that promote ecosystem service synergies in the agroecosystems of the Mediterranean region.

\section{Materials and Methods}

\subsection{Literature Search}

A literature search was conducted using Scopus between March and December 2018. No restriction on the publication date was set and original studies and reviews published in English until March 2018 were considered in this study. To identify relevant publications about agroecosystem services in the Mediterranean region, we used different combinations of the search terms "ecosystem service", "agroecosystem", "agroecosystem service", "Mediterranean", "biodiversity" and "agricultural ecosystem service". In order to include publications covering ecosystem services without using the terms "agroecosystems", "agroecosystem services" or "ecosystem service" in the search, it was decided to carry out searches using specific ecosystem service categories. Combinations of the search terms "Mediterranean" and "agriculture" were adopted with ecosystem services as classified by The Economics of Ecosystems and Biodiversity $\left(\mathrm{TEEB}^{1}\right.$ ) classification system, and were namely pollination, soil fertility, nutrient cycling, habitat for species, carbon sequestration, pest control, food production, soil erosion, freshwater, raw material, climate change, tourism and cultural. This choice of these ecosystem service specific keywords was based on results obtained during the first stage of the literature review when generic terms were used.

\subsection{Selection Criteria}

The selection process included the screening of the title, keywords and abstract first and then the full paper study. The search results summed up 573 papers that without duplicates resulted in a total

1 The Economics of Ecosystems \& Biodiversity: http://www.teebweb.org/ (accessed on 26 May 2020). 
of 480 . The first selection was done by checking the title and abstract, and a general characterisation of the papers; 435 publications were refused, while 45 were considered eligible according to accepting the selection criteria described below. In the second stage, the full text was assessed, and only papers related to assessments of agroecosystem services were considered. In this selection stage, the refusing criteria were the same as those indicated below. At the end of this process, 41 papers were finally selected, as shown in Figure 1 and Appendix A (Table A1). Each paper was considered relevant if it met at least one of the criteria listed below:

(a) Assessed the link between biodiversity and the ecosystem service supplies or flows in Mediterranean agroecosystems;

(b) Considered human or natural drivers impacting on Mediterranean agroecosystems and ecosystem services;

(c) Considered trade-offs and synergies between agroecosystem services in the Mediterranean region;

(d) Carried out a quantification of market and/or non-market values of agroecosystem services in the Mediterranean region;

(e) Analysed agricultural policies and practices that enhance biodiversity and agroecosystem services in the Mediterranean region.

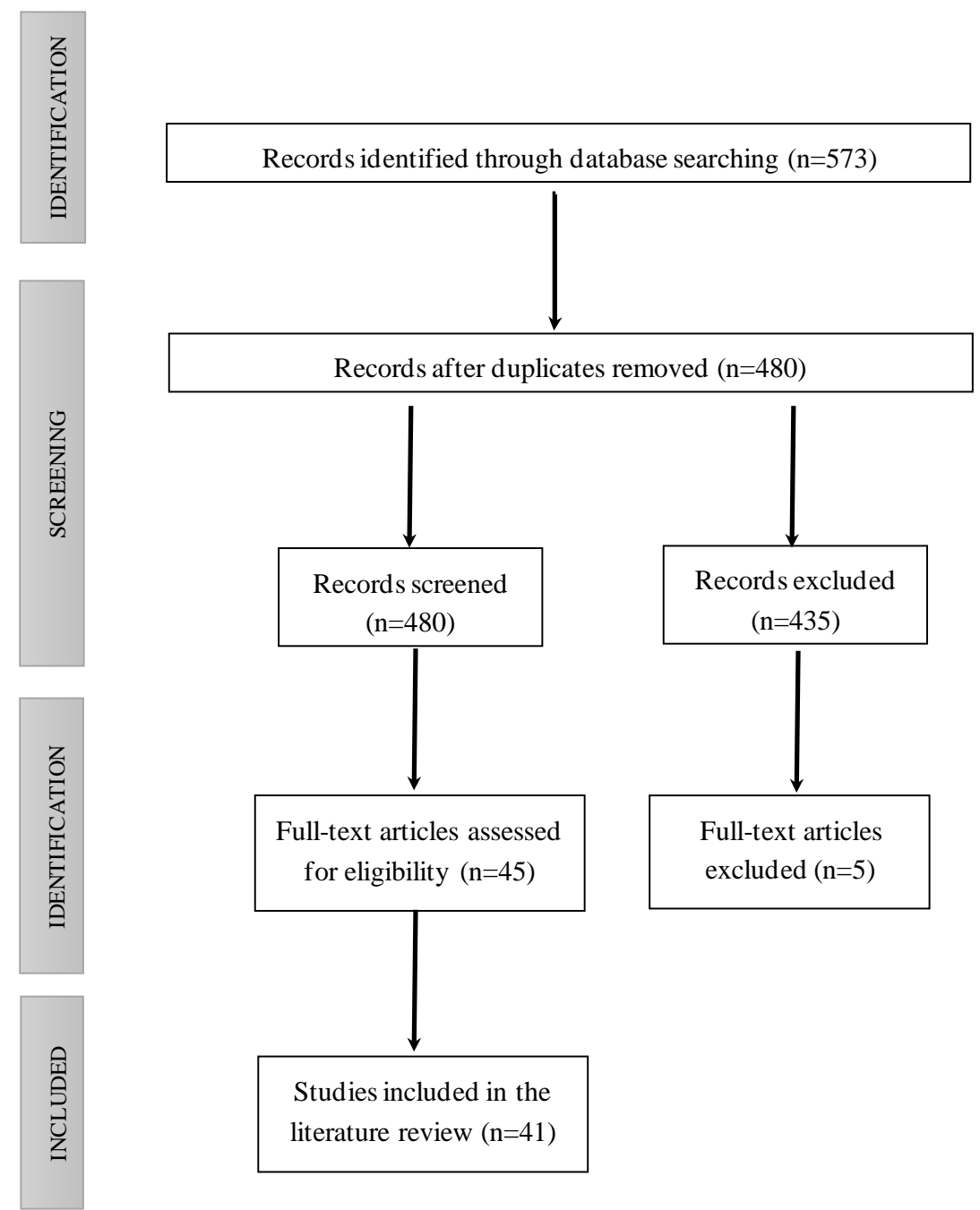

Figure 1. Flow chart showing the methodology and selection processes applied in the present review. 


\subsection{Data Extraction}

Relevant data were extracted from the 41 selected papers, according two main categories: (1) general information about the paper and (2) the assessment of ecosystem services in Mediterranean agroecosystems. During the data extraction stage, each study was characterised by assigning it to one of the stages identified in the ecosystem services cascade model [17]. Within this framework, biophysical structures and processes define ecosystem functions, or the interactions between biodiversity and ecosystem processes that underpin the capacity of ecosystems to provide ecosystem services. Ecosystem service flows are a measure of the use of ecosystems and their services leading to human well-being [17]. We have categorised ecosystem services according to TEEB [18] classification. The following features were extracted from the selected papers:

1.1 Year of publication;

1.2 Country of affiliated institution of the first author;

1.3 Paper perspective: productive, economic, social, conservation, mixed;

1.4 Type of article: research or review;

1.5 Type of analysis: quantitative, qualitative, conceptual;

1.6 Study location: Mediterranean Basin, European Mediterranean, northwest Mediterranean, northeast Mediterranean, Northern Africa;

1.7 Scale of the study: Mediterranean Basin, European Mediterranean region, northern western Mediterranean, northern eastern Mediterranean, national, local;

2.1 TEEB ecosystem service category: provisioning, regulating, habitat or supporting, cultural services;

2.2 TEEB ecosystem services considered: crop provisioning, pollination, soil fertility, nutrient cycling, habitat for species, carbon sequestration, pest control, food production, soil erosion, freshwater, raw material, tourism and recreation, cultural value, various ( $>4$ ecosystem services);

2.3 Ecosystem services cascade model stage considered: biophysical structure, ecosystem function, ecosystem service, benefits, socio-cultural and economic value;

2.4 Drivers and pressures on agroecosystems and ecosystem services;

2.5 Synergies between agroecosystem services;

2.6 Type of agroecosystem: arable, agroforestry, multi-crop, grassland;

2.7 Type of crop: e.g., wheat, vineyard, olive, rice;

2.8 Type of cultivation system: homogenous, heterogeneous;

2.9 Involvement of stakeholder groups: farmers, agronomists and other experts, residents, tourists, researchers.

A subsequent step was carried out to identify drivers and pressures and to assess potential interactions between these and different cropping systems and agroecosystem services. Pressures identified in these studies (2.4) were: agricultural practices, climate change, demographics, habitat loss and land use change.

\subsection{Data Analysis}

Descriptive statistics were calculated for each data variable extracted during this review. Additionally, in order to analyse the type of studies and association with type of culture and ecosystem services, an adjacency matrix was created for each type of interaction. Subsequently, hierarchical clustering with Euclidean distance, or Jaccard distance for binary datasets when dealing with individual studies, was used. Clustering was carried out to assess how frequently different ecosystem services were studied together, to identify similarities between studies in terms of the ecosystem service cascade model stage dealt with in the article, and to classify drivers and pressures according to the number of links to the type of culture and ecosystem service data recorded from this literature review [19]. This analysis was carried out using the heatmap.2 function from gplots package [20]. 
For the studies that were categorised as identifying ecosystem service synergies, an adjacency matrix linking different ecosystem services was created with each representing the number of links identified in the literature. This was then used to visualise a network of ecosystem service synergies using the igraph [19] and qgraph [20] packages. Data processing was performed in R 3.6.3 [21].

\section{Results and Discussion}

\subsection{Overview of the Selected Papers}

The papers selected for this review were dated from 1998 until February 2018. Most of the literature retrieved during the searches was published between 2006 and 2018. The number of publications increased with time, reaching a peak in 2016 (Figure 2a). Most of the literature was classified as original research ( $85 \%$; Figure $2 \mathrm{~b}$ ) and carried out quantitative analysis (74\%). Most had a productive (29\%) or a conservation/productive focus $(27 \%)$, that is, focusing on crop production and the interaction between crop production and biodiversity and ecosystem services. These categories were followed by studies categorised as mixed (20\%; categorised as having three or more scientific focuses) and conservation/social (10\%) focuses (Figure 2c). Most of the studies were carried out in arable (27\%) and permanent $(27 \%)$ crops and in multi-crop $(10 \%)$ or agroforestry $(7 \%)$ systems, whilst $12 \%$ of the papers considered pasture or livestock-based farming systems. The involvement of stakeholders was only recorded in only $12 \%$ of the considered studies.

(a)

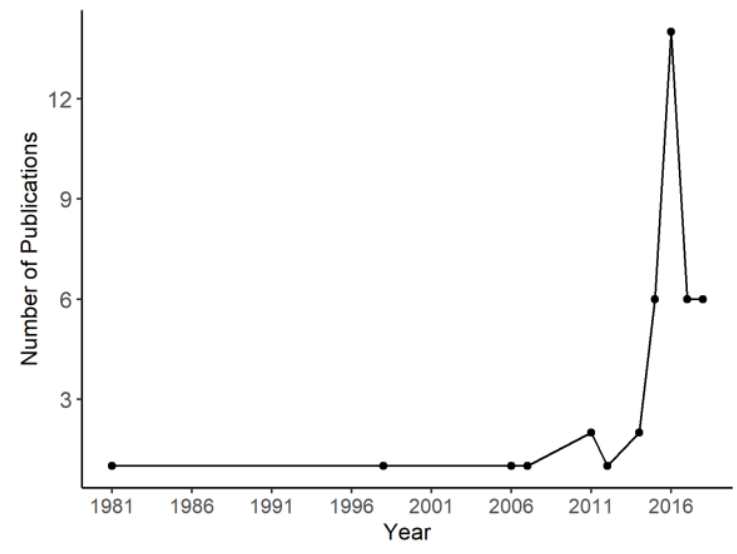

(c)

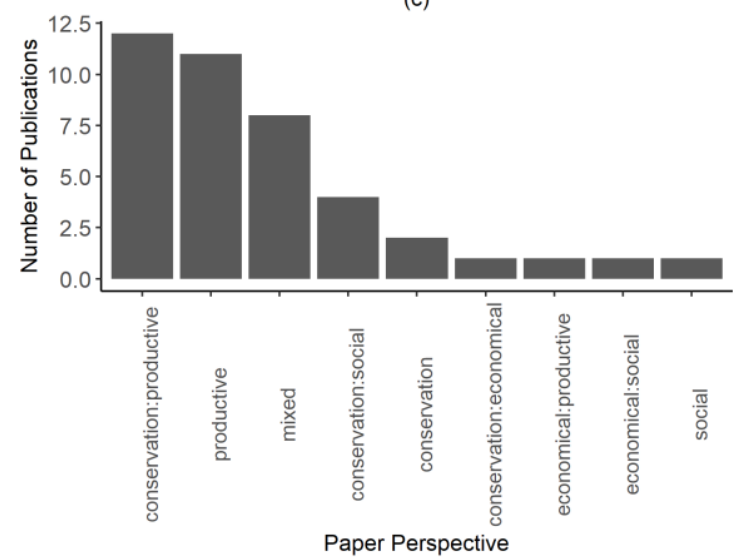

(b)

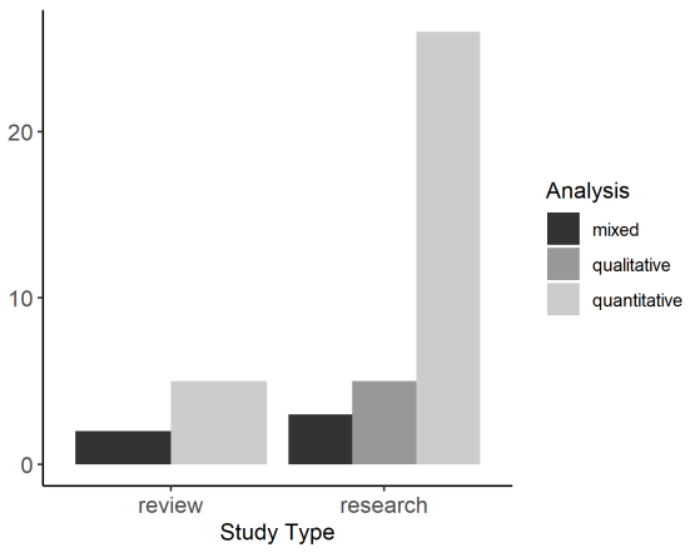

(d)

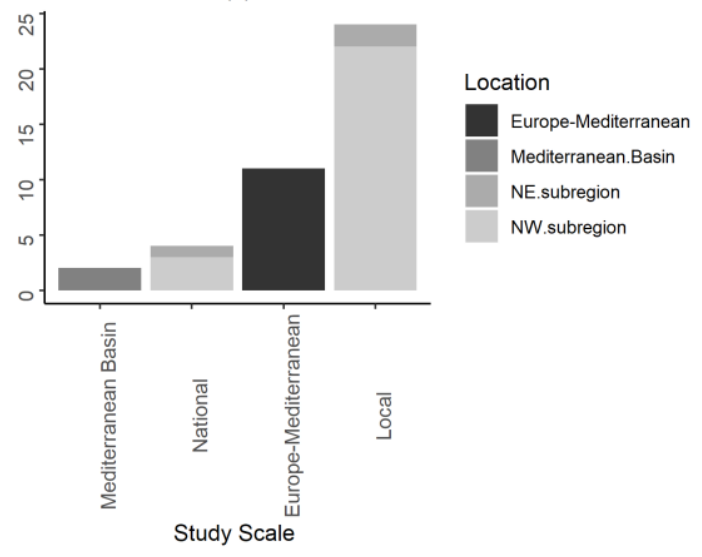

Figure 2. A descriptive analysis of the selected 41 studies on Mediterranean agroecosystem services. (a) Number of publications per year. (b) Number of studies according to the type of analysis. (c) Number of studies according to the paper focus (productive, economic, social, conservation, mixed (when 3 categories or more could be assigned to the paper)). (d) Number of studies according to the location and the scale of the study. 
Of the selected papers, $31 \%$ studied just one ecosystem service, more than half of the articles (61\%) assessed between 2 to 10, and a minority (8\%) studied more than 10 ecosystem services. A significant part of the papers $(67 \%)$ referred to case studies carried out at local scale. A total of two studies (corresponding to $5 \%$ ) were carried out at Mediterranean Basin regional level, whilst $27 \%$ of the studies were carried out in the European Mediterranean subregion; $61 \%$ of the studies were from the north-west subregion (corresponding to France, Italy, Portugal, Spain and Malta), whilst $7 \%$ were from the north-east subregion (Greece). Studies from collaborative research focusing on several European countries was classified being from the European Mediterranean region, whilst studies carried out at national scales were mostly carried out in specific countries for the other two regions shown in Figure $2 \mathrm{~d}$. The leading authors in $37 \%$ and $15 \%$ of the publications were either from Spain or Italy. None of the literature included in this review was from countries in Northern Africa, highlighting a potential geographical bias in our methodology, which did not consider grey literature and indexed studies in English were considered in this review, and potentially a geographic knowledge gap [12].

\subsection{Ecosystem Services}

A total of 14 ecosystem services were considered by studies selected in this review. Most of the reviewed papers dealt with regulating ecosystem services with a total of nine regulating, three provisioning, two cultural and two habitat or supporting services identified in this review (Figure 3). The most studied ecosystem services were habitats for species (supporting ecosystem service), freshwater provisioning and quality regulation, pest control and pollination regulating ecosystem services, whilst a total of seven studies considered or assessed various $(>4)$ ecosystem services.

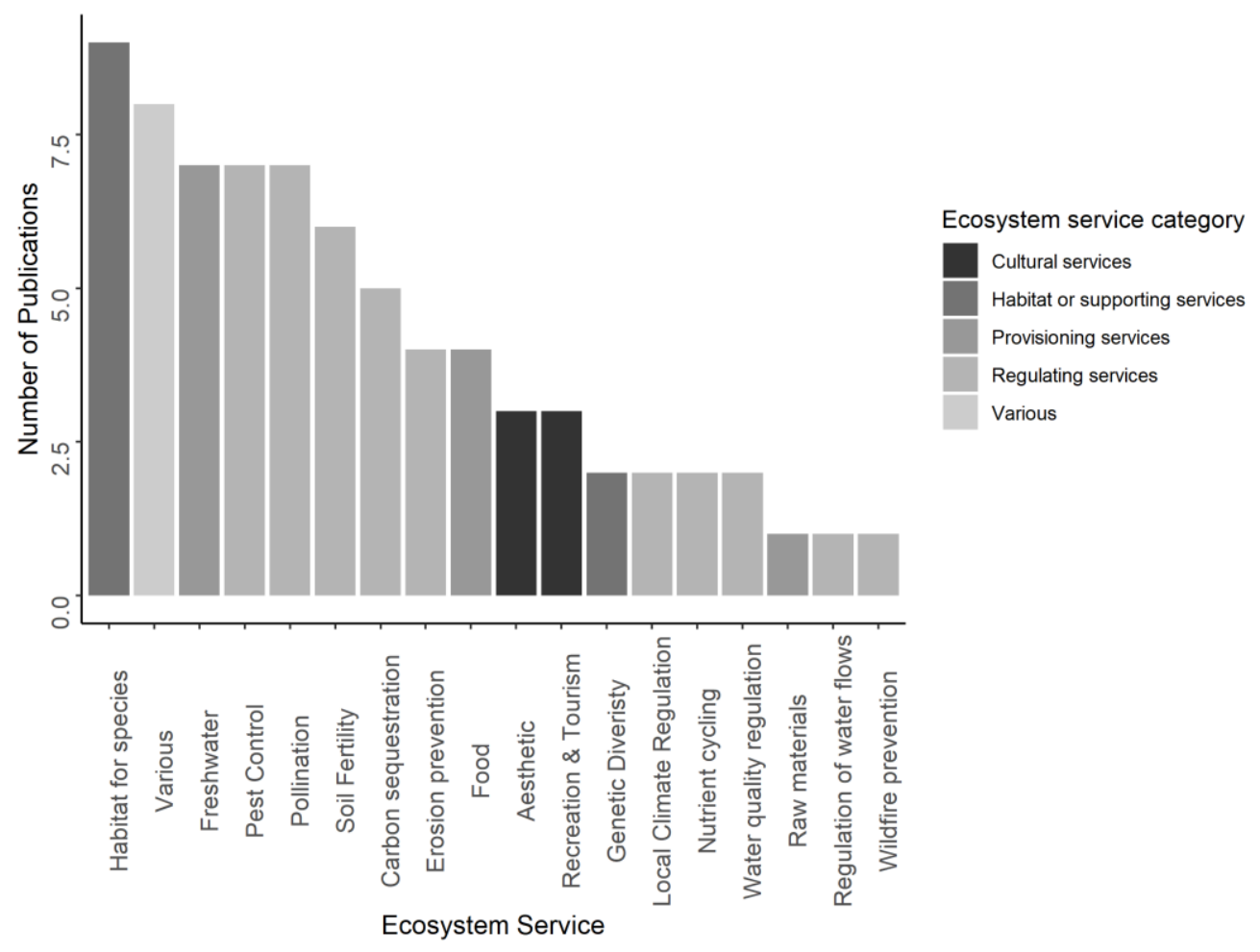

Figure 3. Frequency distribution of studies investigating ecosystem services.

During the extraction stage, each ecosystem service was characterised by assigning it to one of the stages identified in the ecosystem services cascade model, which links ecosystem biophysical structure and ecosystem functions to ecosystem service flows, benefits and values [17]. Most studies focused on the biophysical structure of ecosystems, as shown in Figure 4, which together with ecosystem functions define the ecosystem service capacity. A total of 83 ecosystem service capacity indicators 
were identified in this review (Appendix B, Table A2). The literature assessing the biophysical structure was clustered with studies assessing ecosystem service flows, as shown in Figure 4, defined here as the actual production of ecosystem services [22], and a total of 17 indicators were identified for ecosystem service flows. Many fewer studies have carried out an assessment of the social and economic benefits of ecosystem services from Mediterranean agroecosystems, as shown in Figure 4. Indicators identified for this final stage of the cascade model mostly used market prices for food production or willingness-to-pay values for biodiversity conservation and cultural ecosystem services. A total of 110 ecosystem service indicators were identified for the ecosystem services considered in this review, as shown in Table 1. Erosion prevention and maintenance of soil fertility ecosystem services had the largest number of indicators (33), followed by pollination, habitat for species and pest control (12 each).

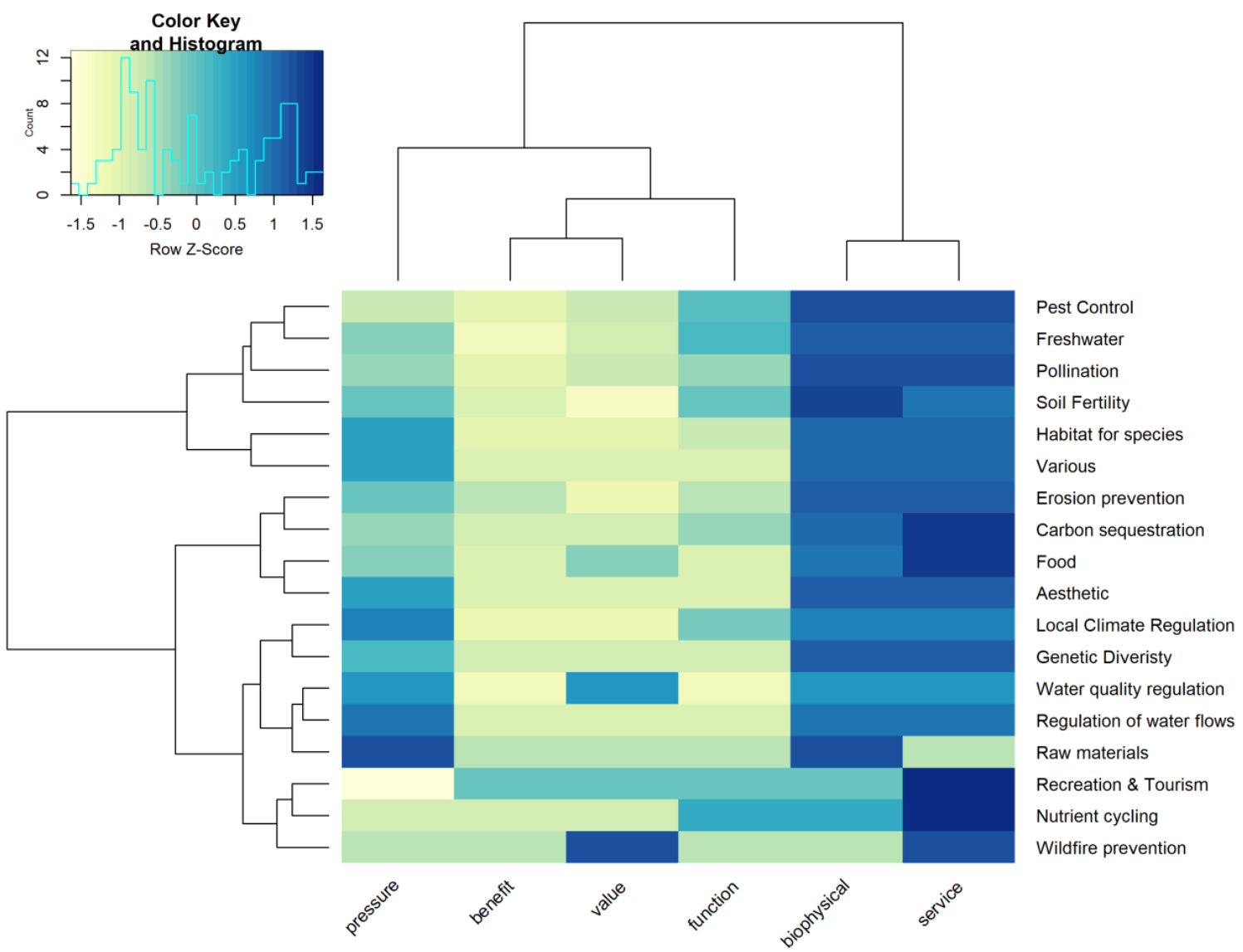

Figure 4. An overview of the ecosystem service cascade model stage associated with different ecosystem services. Dendrograms obtained through hierarchical clustering, and using Jaccard distance, represent similar association of studies in terms of the studied ecosystem service cascade model stage (columns) and the identified ecosystem services (rows).

The number of papers focusing on cultural ecosystem services was relatively low, but studies that included this category were more often associated with an assessment of the arising benefits and values for different beneficiary groups, including residents and tourists [23,24]. This is in line with observations that food production is often considered as being an important valorisation chain that outweighs the benefits and contributions of ecosystem services to other social and cultural aspects [11,25]. Aesthetic value and sense of identity were strongly valued by residents, whilst dry-stone walls, hedges and tree rows have synergistic impacts on biodiversity conservation and aesthetic and cultural heritage value of landscapes [26]. Similarly, intermediate intensity management in vineyards and olive groves, and in field margins, at the local scale and habitat availability within the surrounding landscape were associated with increased plant diversity. These results indicate that there are benefits in not 
focusing exclusively on private benefits arising from agricultural production and where economic valuation relies not only on productivity but also on heritage and landscape values; niche products can be promoted whilst also favouring biodiversity conservation [27]. Rodríguez-Ortega et al. (2016) identified two psychographic profiles affecting willingness-to-pay for ecosystem services provided by Mediterranean high nature value farmland, both of which show concerns about forest wildfires but differ in their priorities towards delivery of quality products (productivist profiles) versus those with a stronger prioritisation of biodiversity conservation and landscape maintenance (conservationist profile). These profiles strongly impact on the willingness-to-pay, with conservationists willing to pay more for key ecosystem services [28].

Table 1. Number of ecosystem service indicators as categorised into capacities, flows and benefits.

\begin{tabular}{ccccc}
\hline \multirow{2}{*}{ Ecosystem Service } & \multicolumn{3}{c}{ Number of Ecosystem Service Indicators } \\
\cline { 2 - 5 } & Capacity & Flow & Benefit & Total \\
\hline Food provision & 6 & 3 & 1 & 10 \\
\hline Raw material & 2 & 1 & 0 & 3 \\
\hline Fresh water & 3 & 2 & 0 & 5 \\
\hline Wastewater treatment & 1 & 1 & 1 & 3 \\
\hline Pollination & 9 & 2 & 1 & 12 \\
\hline Erosion prevention and maintenance of soil fertility & 27 & 6 & 0 & 33 \\
\hline Habitat for species & 7 & 0 & 5 & 12 \\
\hline Carbon sequestration and storage & 3 & 0 & 1 & 4 \\
\hline Biological control & 12 & 0 & 0 & 12 \\
\hline Maintenance of genetic diversity & 1 & 0 & 0 & 1 \\
\hline Local climate and air quality & 0 & 1 & 0 & 1 \\
\hline Moderation of extreme events & 1 & 0 & 0 & 1 \\
\hline Aesthetic appreciation and culture & 11 & 1 & 1 & 13 \\
\hline Total: & $\mathbf{8 3}$ & $\mathbf{1 1}$ & $\mathbf{1 0}$ & $\mathbf{1 1 0}$ \\
\hline
\end{tabular}

\subsection{Drivers and Pressures Acting on Mediterranean Agroecosystems}

The pressures acting on Mediterranean agroecosystems and their services were categorised into four categories. Pressures acting on Mediterranean agroecosystems were identified from $44 \%(n=18)$ of the studies, with agricultural practices and management $(n=10)$ being the most frequently studied, followed by demographic and socioeconomic changes (5), and climate change (2) and habitat loss and land use change (2).

Agricultural practices impacting on Mediterranean agroecosystem and ecosystem services were studied in permanent, arable and agroforestry systems, as shown in Figure 5a, and impact on multiple ecosystem services but were more strongly associated with regulating services and habitats for species (supporting ecosystem service), as shown in Figure 5b. Agroforestry and multi-cropping systems generally had a positive impact on biodiversity and ecosystem services. Agroforestry systems were associated with improved erosion control, biodiversity and soil fertility [29], whilst scattered trees were identified as being important to maintain grassland diversity in Mediterranean dehesas [30]. Similarly, agroecosystems in which agrarian and forestry activities co-exist were associated with improved optimisation of freshwater flows and with the supply of multiple ecosystem services [31]. Agricultural intensification in arable systems was associated with reduced plant species and functional diversity [32], whilst crop rotation increased the diversity and composition of soil microbial communities [33] and intercropping in vineyards, even temporarily, was associated with improved soil functioning [34]. 

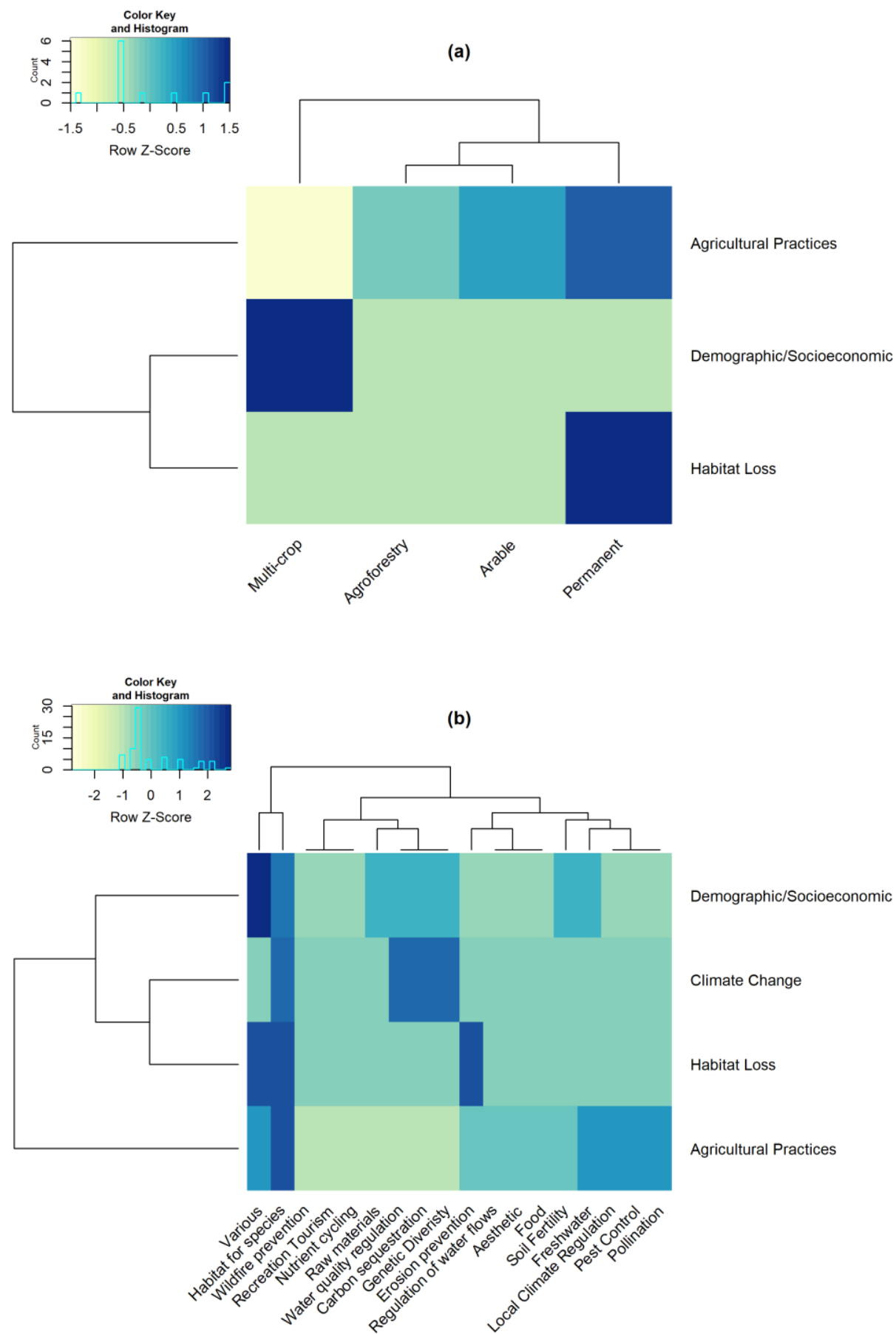

Demographic/Socioeconomic

Climate Change

Habitat Loss

Agricultural Practices

Figure 5. Association between drivers and pressures (rows) and (a) cropping system and (b) ecosystem service (columns). Dendrograms obtained through hierarchical clustering, and using Euclidean distance, represent similar association of studies in terms of the considered pressures and cropping system or ecosystem service stage.

Literature indicates a positive impact of extensive production systems on biodiversity conservation and multiple regulating and ecosystem services [24,26,35]. However, the low profitability of these extensive production systems has prompted either the intensification or the abandonment of Mediterranean agro-ecosystems [31,36,37]. In this review, demographic and socio-economic drivers, and the associated loss of agricultural habitats, were associated with multi and permanent cropping systems, as shown in Figure 5a, and impacts on multiple ecosystem services were identified, as shown in 
Figure $5 \mathrm{~b}$. Whilst the importance of these ecosystem services was appreciated by different stakeholder groups, it was more strongly perceived when the ecosystem services were directly experienced and sustained local livelihoods [24,28].

Population growth in the Mediterranean and sources of impacts of tourism and other industries have transformed agricultural landscapes into urban and industrial landscapes over the past decades, leading to the loss of food provisioning and regulating services. In a case study from a coastal landscape in Barcelona, Spain, industrial and residential development increased from $1.7 \%$ to $47.5 \%$ and was associated with an increase in population densities and land cover surfaces with low capacity to provide ecosystem services [38]. Similarly, observations were obtained from Crau (France) and Valencia (Spain) and Emilia-Romania (Italy), where reductions in cropland cover have been observed and further loss of agricultural land to urban sprawl is predicted until 2030 [39]. A rural-urban gradient in multifunctionality was observed in a study carried out in Malta, where agroecosystems were associated with high capacities and flows of ecosystem services [13].

In addition, to the demographic and socio-economic drivers, climate change is expected to lead to further contraction of the agricultural area in Southern Europe that is driven by future decreases in the relative profitability of the agricultural sector as a consequence of increased heat and drought stress and reduced irrigation water availability [10]. These results complement other observations indicating future reductions in irrigated areas and the intensification and expansion of rain-fed cropping systems as the most significant adaptation options for the Mediterranean region when no or low water irrigation efficiency improvements are carried out [40]. Irrigation is also associated with changes to farmland plant communities, and was associated with a reduction in habitat availability for bird diversity in cereal agroecosystems [36], whilst flood irrigation was associated with increased cover of alien plant species and a reduction in the availability of forage for pollinators in orchards when compared to the more efficient drip irrigation [41].

\subsection{Ecosystem Service Synergies}

A total of 12 studies identified ecosystem service synergies in Mediterranean agroecosystems. Studies assessing agroecosystem service synergies were carried out in permanent $(n=4)$, arable $(n=3)$, multi-crop (4) and agroforestry (2) cropping systems, and a total of 3 studies considered livestock farming. The visualised network of interactions identified multiple ecosystem service synergies, but no specific interaction dominated the results, as shown in Figure 6, and weak interactions were observed between several ecosystem services. The ecosystem services with the largest number of interactions recorded were food provisioning (6), carbon sequestration (6) and habitats for species (5). The lowest number of synergies were recorded for pollination, pest control and erosion regulation (1) ecosystem services and may indicate that these may be less studied with other ecosystem services. Whilst our review does not indicate that specific interactions between ecosystem services emerges to dominate the literature, our literature does provide evidence of the multifunctionality of agroecosystems, and practices that favour one ecosystem service were often associated with multiple ecosystem services [33,35,37]. For example, shrub and tree cover in permanent crops and agroforestry were associated with biodiversity conservation and soil erosion control [30,35], whilst managed olive groves were associated with pollination ecosystem services [42]. Important synergies were also identified between livestock farming, biodiversity conservation and aesthetic and cultural values. The lack of valuation of ecosystem services arising from pasture-based farming systems is associated with displacement by other economic activities [37]. This contrasts with trends shown for pressures, where changes in agricultural practices, particularly through intensification, were associated with a reduction in ecosystem services capacities and flows and indicate a potential trade-off between intensive agricultural production and regulation and cultural ecosystem services [31,32]. 


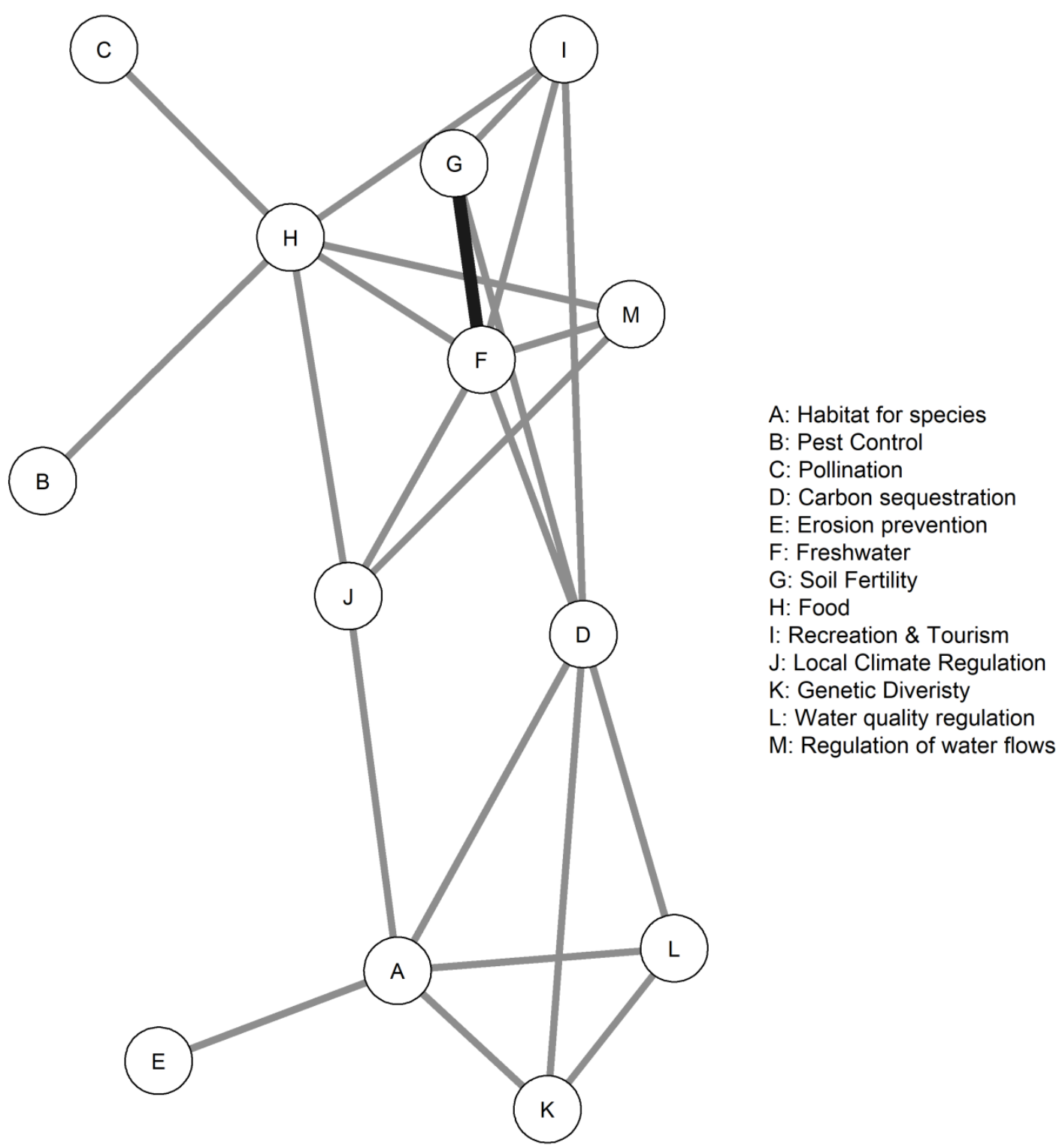

Figure 6. A network diagram showing the linkages between different agroecosystem services in studies that identified ecosystem service synergies.

\subsection{Gaps and Recommendations for Future Research}

This review has identified key patterns relating to the assessment of agroecosystem services in the Mediterranean region, and the results obtained provide key indications relating to the contributions of Mediterranean agroecosystems to ecosystem services and associated benefits to human well-being. Nevertheless, the long cultural history that led to co-evolved social-ecological systems makes it difficult to understand the processes and interactions between ecosystems and human society. Additionally, the wide diversity of social and ecological conditions present within the region make it even more complex to identify interactions and processes, and to capture trends, that apply for the entire region and for the different cropping and livestock systems [11]. Within this context, the methodological choices made in this review, such as, for example, arising from only published literature in English being considered, are likely to have influenced the results obtained (e.g., through geographic bias). Similarly, substantial literature about the cultural landscapes of the Mediterranean region, their importance for biodiversity, ecosystem processes and ecosystem services, exists but this literature may have not been captured in our review given the methodological choice of focusing more specifically on 
agroecosystems and agroecosystem management and the assessment of services in Mediterranean agroecosystems $[43,44]$.

Most of the studies identified in this review have focused on the assessment of ecosystem structure and services in the European Mediterranean region, whilst only a small fraction of the studies included stakeholder participation in ecosystem service assessments. Multiple synergies between ecosystem services were recorded but no specific interaction was more frequently studied, indicating that agroecosystems are multifunctional and provide multiple ecosystem services and benefits. The reviewed literature provides evidence of the contributions of extensive or traditional agricultural practices on biodiversity and ecosystem services, and indicate that the conservation of the latter depends on the maintenance of less intensive practices [4]. On the other hand, a trade-off between intensive agricultural practices favouring food provisioning and ecosystem services capacities and flows has been recorded in several studies and for various ecosystem services.

Ecosystems are complexes where biotic and abiotic components interact, and these interactions influence the physicochemical and biological characteristics of ecosystems and ecological processes, which mediate ecosystem services. Biotic-abiotic interactions largely occur at the level of ecological processes, rather than services, with biodiversity acting as a regulator of ecosystem services [5]. Literature assessing the functioning of ecosystems and biodiversity-ecosystem functioning relationships in Mediterranean agroecosystems was limited, indicating a potential knowledge gap in the literature, limiting our ability to predict the impact of future environmental change on ecosystem services. Additionally, whilst few studies have predicted the impact of climate change on agricultural production practices, our understanding of the impacts of this global stressor on biodiversity and biodiversity-ecosystem functioning in the Mediterranean region remains limited.

The management of agroecosystems to maintain agroecosystem multifunctionality, whilst adapting to local and global stressors which impact on the profitability of agricultural production [10] and ecosystem services [3], is considered as being important for biodiversity conservation and human well-being within the region. In addition to productive and conservation approaches, already widely implemented, practices that balance agricultural productivity with social and ecological benefits $[4,10,12]$ should be considered and promoted in agri-environmental measures within the region. This is considered as a gap in existing scientific literature, as demonstrated by the relatively low number of studies that consider the socio-cultural context and which include stakeholder participation and indicates the need for more integrated ecosystem service approaches to support decision-making. Integrated approaches need to consider the different values associated with agroecosystems, which extend beyond productivist approaches normally assigned to cropping, livestock and agroforestry systems, to ensure that ecosystem service flows are sustainable and ecosystem service synergies promoted through sustainable intensification processes that favour food provisioning services but also contribute to other environmental, socio-cultural and economic benefits.

\section{Conclusions}

This study has reviewed literature to identify the current state and biases of ecosystem service assessment in agroecosystems within the Mediterranean region, and to evaluate pressures impacting on agroecosystems and their services and practices that promote ecosystem service synergies in Mediterranean agroecosystems. A total of 41 papers were selected for analysis from a set of 573 potentially relevant papers. These studies mostly originated from the European Mediterranean subregion and assessed a total of 14 ecosystem services from all ecosystem service categories considered. Pressures arising from agricultural practices and demographic and socio-economic changes were the most frequently considered whilst few studies considered the impact of climate change on agroecosystem and associated services and benefits to human well-being. Research has focused on the assessment of ecosystem structure and services, whilst knowledge gaps about ecological processes determining the responses of agroecosystems to future environmental change, the involvement of stakeholders and the consideration of the socio-cultural context were identified. We consider that 
approaches that integrate biophysical, socio-cultural and economic perspectives are necessary to maintain the multifunctionality of the Mediterranean's agroecosystems and their contributions to human well-being.

Author Contributions: Conceptualisation, M.V.B. and L.S.; methodology, M.V.B. and L.S.; validation, M.V.B., R.S. and L.S.; formal analysis, M.V.B.; writing-original draft preparation, M.V.B., R.S. and L.S.; writing-review and editing, M.V.B., R.S. and L.S.; visualisation, M.V.B.; supervision, M.V.B.; project administration, M.V.B., R.S. and L.S.; funding acquisition, M.V.B. All authors have read and agreed to the published version of the manuscript.

Funding: This research was supported by the DIVERCROP project funded by the Malta Council for Science and Technology through the ARIMNet2 Joint Initiative of Member States, Associated Countries and Mediterranean Partner Countries. This research was supported by the ReNature project. This project has received funding from the European Union's Horizon 2020 research and innovation programme under grant agreement No 809988.

Acknowledgments: The authors acknowledge Dawn Grech who has read this review and provided comments on an earlier draft.

Conflicts of Interest: The authors declare no conflict of interest.

\section{Appendix A}

Table A1. List of articles included in this review sorted in chronological order.

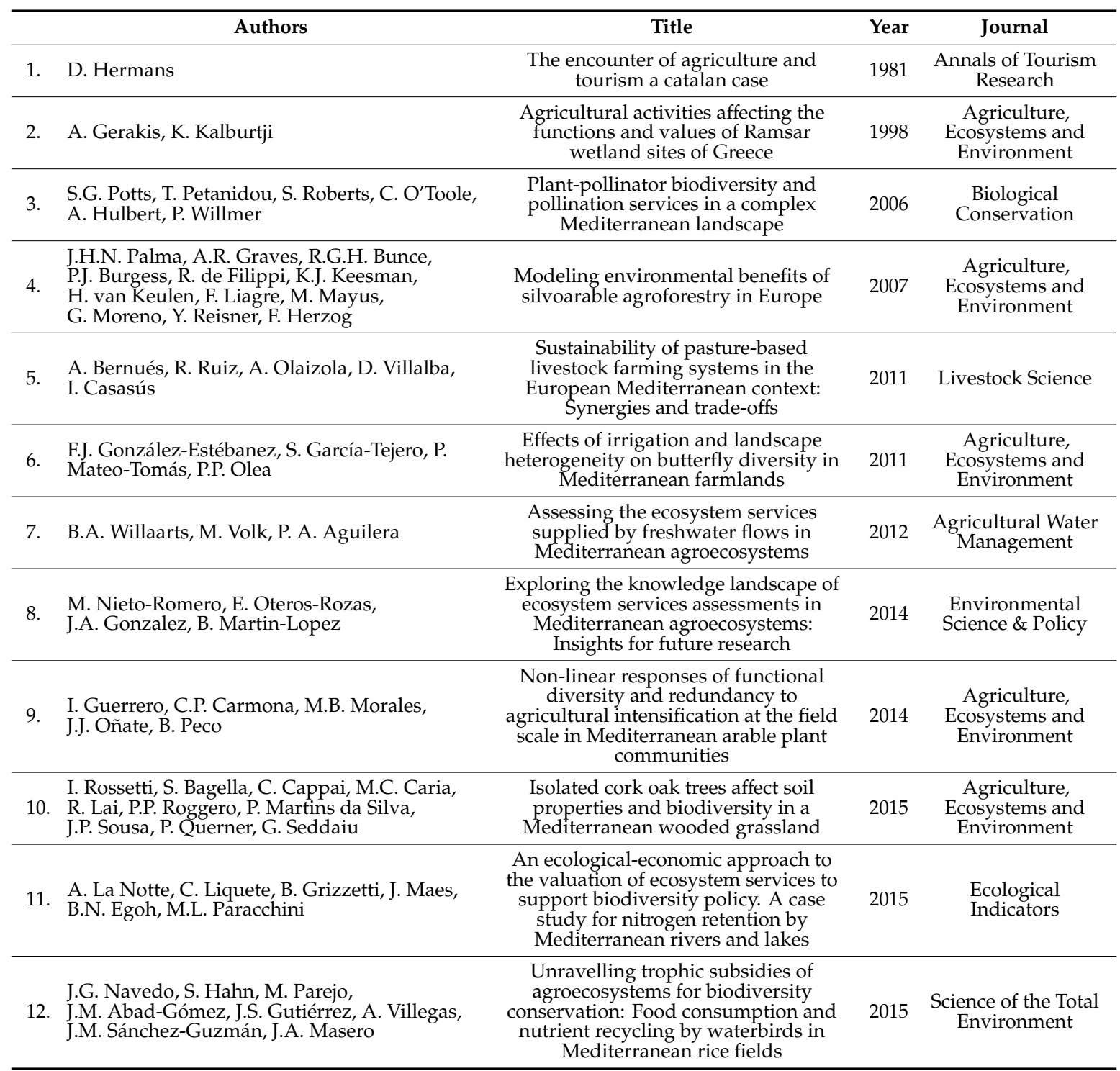


Table A1. Cont.

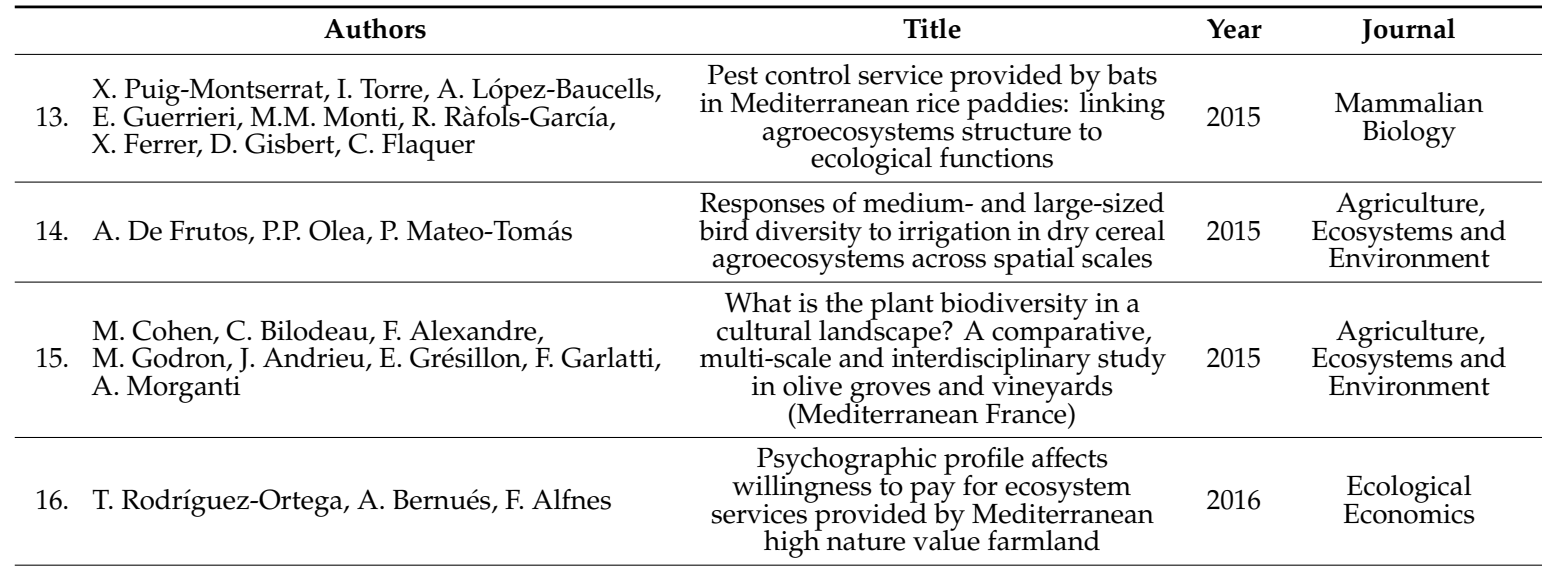

R.E. Creamer, S.E. Hannula, J.P. Van Leeuwen, D. Stone, M. Rutgers, R.M. Schmelz, P.C. de Ruiter, N. Bohse Hendriksen, T. Bolger, M.L. Bouffaud, M. Buee, F. Carvalho, D. Costa,

17. T. Dirilgen, R. Francisco, B.S. Griffiths,

R. Griffiths, F. Martin, P. Martins da Silva,

S. Mendes, P.V. Morais, C. Pereira, L. Philippot,

P. Plassart, D. Redecker, J. Römbke, J.P. Sousa,

M. Wouterse, P. Lemanceau

T. Dirilgen, J. Arroyo, W.J. Dimmers, J. Faber,

D. Stone, P. Martins da Silva, F. Carvalho,

R. Schmelz, B.S. Griffiths, R. Francisco,

R.E. Creamer, J.-P. Sousa, T. Bolger

Ecological network analysis reveals the inter-connection between soil biodiversity and ecosystem function as

affected by land use across Europe

Applied Soil Ecology

B.S. Griffiths, J. Römbke, R.M. Schmelz,

A. Scheffczyk, J.H. Faber, J. Bloem, G. Pérès,

D. Cluzeau, A. Chabbi, M. Suhadolc, J.P. Sousa

P. Martins da Silva, F. Carvalho, S. Mendes,

P. Moraish, R. Francisco, C. Pereira, M.

19. Bonkowski, S. Geisen, R.D. Bardgett,

F.T. de Vries, T. Bolger, T. Dirilgen, O. Schmidtl,

A. Winding, N.B. Hendriksen, A. Johansen,

L. Philippot, P. Plassart, D. Bru, B. Thomson,

R.I. Griffiths, M.J. Bailey, A. Keith, M. Rutgers,

C. Mulder, S.E. Hannula, R. Creamer, D. Stone

Mite community composition across a

European transect and its relationships to variation in other components of soil biodiversity

$2016 \quad \begin{gathered}\text { Applied Soil } \\ \text { Ecology }\end{gathered}$

Selecting cost effective and policy-relevant biological indicators for European monitoring of soil biodiversity and ecosystem function
2016

Ecological Indicators

Studying the historical evolution of

20. A.M. Santana-Corderoa, E. Ariza, F. Romagosa 21. E. Soy-Massoni, J. Langemeyer, D. Varga,
M. Sãez, J. Pintó ecosystem services to inform management policies for developed shorelines

The importance of ecosystem services in coastal agricultural landscapes: Case study from the Costa Brava, Catalonia, Ecosystem Services

$2016 \quad \begin{gathered}\text { Environmental } \\ \text { Science \& Policy }\end{gathered}$

2016 Ecosystem Services

Do European agroforestry systems enhance biodiversity and ecosystem

services? A meta-analysis

M. Torralba, N. Fagerholm, P.J. Burgess, G. Moreno, T. Plieninger

23. N. Fagerholm, M. Torralba, P.J. Burgess, T. Plieninger

24 A. Lopez-Sanchez, A. San Miguel C. Lopez-Carrasco, L. Huntsinger, S. Roig

C. Salomé, P. Colla, E. Lardo, A. Metay,

25. C. Villenave, C. Marsden, E. Blanchart, P. Hinsinger, E. Le Cadre

A. Bernuésa, E. Tello-García,

26. T. Rodríguez-Ortega, R. Ripoll-Bosch, I. Casasús services assessments around European agroforestry

The important role of scattered trees on the herbaceous diversity of a grazed Mediterranean dehesa

The soil quality concept as a framework to assess management practices in vulnerable agroecosystems: A case study in Mediterranean vineyards

Agricultural practices, ecosystem services and sustainability in High

Nature Value farmland: Unraveling the perceptions of farmers and nonfarmers 
Table A1. Cont.

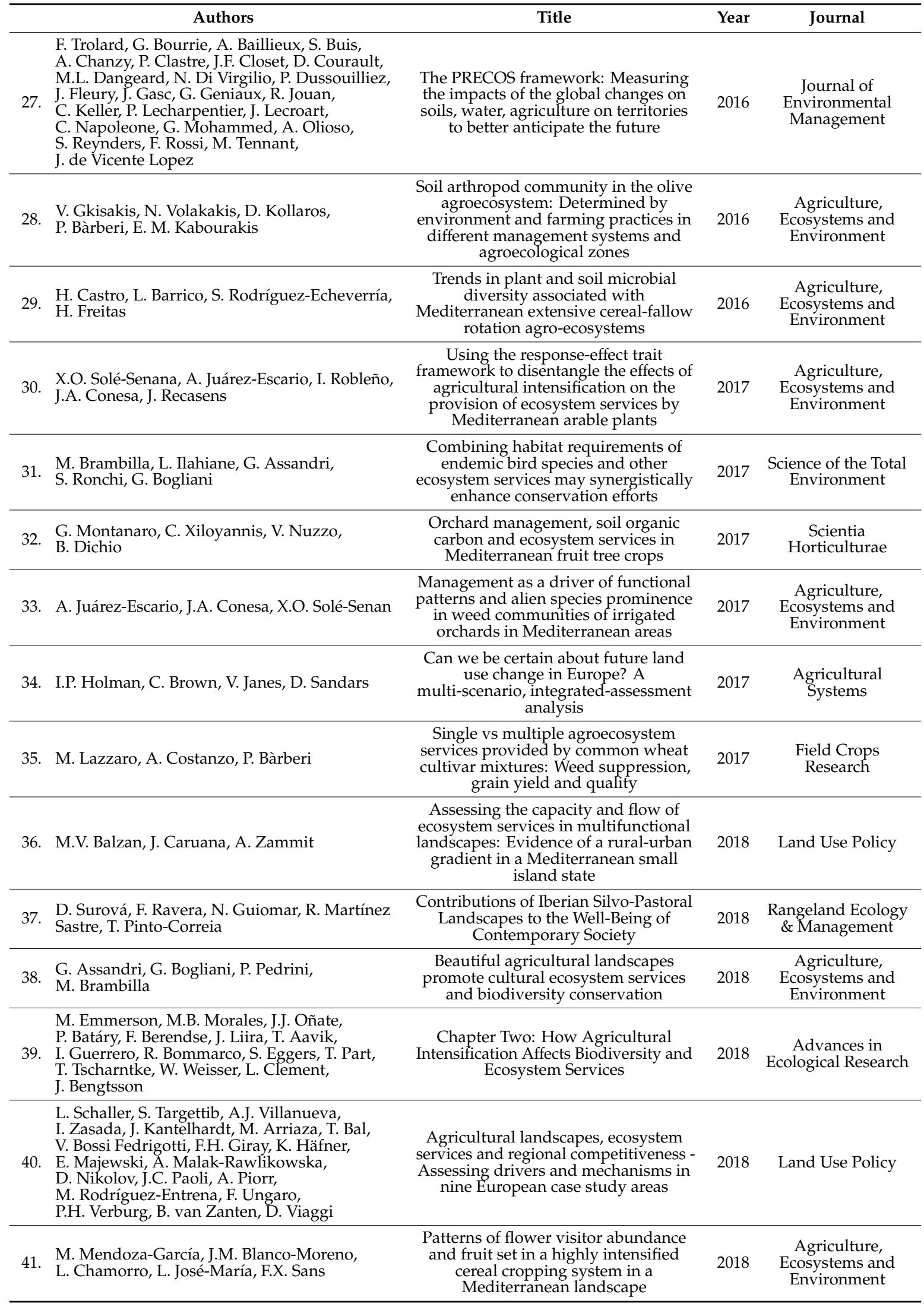




\section{Appendix B}

Table A2. Ecosystem service indicators identified in this review as classified into capacities, flows, benefits.

\begin{tabular}{|c|c|c|c|}
\hline Ecosystem Service & Capacity & Flow & Benefit \\
\hline \multirow{6}{*}{ Food Production } & Wheat production yield (t/ha) [45] & Food production [31] & $\begin{array}{l}\text { Willingness-to-pay of local } \\
\text { residents and tourist [24] }\end{array}$ \\
\hline & Number of spikes $\left(\right.$ per $\mathrm{m}^{2}$ ) [45] & $\begin{array}{c}\text { Downscaled crop } \\
\text { production }\left(\mathrm{t} / \mathrm{km}^{2}\right)[13]\end{array}$ & \\
\hline & Number of seeds per spike [45] & $\begin{array}{l}\text { Number of hives } \\
\left(\text { per km² }^{2}\right)[13]\end{array}$ & \\
\hline & $\begin{array}{l}\text { Beekeepers' habitat preference } \\
\text { (Frequency of responses) [13] }\end{array}$ & & \\
\hline & kernel weight (g) [45] & & \\
\hline & $\begin{array}{l}\text { Number of quality products available for } \\
\text { consumers [46] }\end{array}$ & & \\
\hline \multirow[t]{2}{*}{ Raw Material } & $\begin{array}{l}\text { Rainfed agricultural land (Fodder } \\
\text { production potential) [13] }\end{array}$ & $\begin{array}{c}\text { Livestock (number of } \\
\text { Cattle, Sheep, Goats and } \\
\text { Pigs) } / \mathrm{km}^{2}[13]\end{array}$ & \\
\hline & Land occupation [39] & & \\
\hline \multirow{3}{*}{ Fresh Water } & Soil hydraulic conductivity $(\mathrm{mm} / \mathrm{h})[23]$ & Water infiltration [47] & \\
\hline & Soil macroporosity (\%) [23] & $\begin{array}{l}\text { Drinking water } \\
\text { supply [39] }\end{array}$ & \\
\hline & Risk of water salinity [39] & & \\
\hline $\begin{array}{l}\text { Wastewater } \\
\text { Treatment }\end{array}$ & $\mathrm{NO}_{2}$ deposition velocity $(\mathrm{mm} / \mathrm{s})[13]$ & $\begin{array}{l}\mathrm{NO}_{2} \text { removal flux } \\
(\mathrm{t} / \text { ha/year) [13] }\end{array}$ & $\begin{array}{l}\text { Willingness-to-pay of local } \\
\text { residents and tourist [24] }\end{array}$ \\
\hline \multirow{9}{*}{ Pollination } & $\begin{array}{c}\text { Functional diversity of arable plant } \\
\text { communities (Rao's quadratic } \\
\text { entropy) [48] }\end{array}$ & $\begin{array}{l}\text { Pollen grain deposition } \\
\text { (species/site) [42] }\end{array}$ & $\begin{array}{l}\text { Willingness-to-pay of local } \\
\text { residents and tourist [24] }\end{array}$ \\
\hline & Weed species abundance (\%) [41] & $\begin{array}{l}\text { Crop pollinator } \\
\text { dependency [13] }\end{array}$ & \\
\hline & Butterfly species richness & & \\
\hline & Butterfly species abundance & & \\
\hline & Wheat flowering onset [32] & & \\
\hline & Pollinator visitation probability [13] & & \\
\hline & $\begin{array}{l}\text { Richness and abundance of } \\
\text { wildplants [49] }\end{array}$ & & \\
\hline & Bees abundance [49] & & \\
\hline & Non-bee flower visitor abundance [49] & & \\
\hline \multirow{6}{*}{$\begin{array}{l}\text { Erosion Prevention } \\
\text { and Maintenance } \\
\text { of Soil Fertility }\end{array}$} & Microbial diversity [50] & $\begin{array}{c}\text { Microbial function } \\
\text { (nitrification, } \\
\text { extracellular enzymes, } \\
\text { multiple substrate } \\
\text { induced } \\
\text { respiration) [50] }\end{array}$ & \\
\hline & $\begin{array}{l}\text { Microfauna diversity (nematode trophic } \\
\text { group) [50] }\end{array}$ & $\begin{array}{c}\text { Nitrogen and } \\
\text { Phosphorous recycling } \\
\text { by waterbird species in } \\
\text { rice fields [51] }\end{array}$ & \\
\hline & Fauna abundance (\%) [47] & $\begin{array}{l}\text { N leaching } \\
\text { (kg/ha/year) [52] }\end{array}$ & \\
\hline & $\begin{array}{l}\text { Mesofauna diversity (enchytraeids and } \\
\text { Collembola species) [50] }\end{array}$ & Nitrification [47] & \\
\hline & $\begin{array}{l}\text { Soil runoff yield }(\mathrm{mm}) \text {, soil loss }(\mathrm{mg} / \mathrm{ha}) \\
\text { sediment }\left(\mathrm{kg} / \mathrm{m}^{3}\right)[23]\end{array}$ & $\begin{array}{l}\text { Mineralisable } \\
\text { Nitrogen [47] }\end{array}$ & \\
\hline & Earthworms abundance (\%) [23] & $\begin{array}{l}\text { Microbial } \\
\text { respiration [47] }\end{array}$ & \\
\hline
\end{tabular}


Table A2. Cont.

\begin{tabular}{|c|c|c|c|}
\hline Ecosystem Service & Capacity & Flow & Benefit \\
\hline & $\begin{array}{l}\text { Plant species richness (Shannon } \\
\text { index) [53] }\end{array}$ & & \\
\hline & $\begin{array}{l}\text { Collembola species richness (Shannon } \\
\text { index) [53] }\end{array}$ & & \\
\hline & Floor litter dry matter (t/ha) [53] & & \\
\hline & Waterbird abundance [51] & & \\
\hline & $\begin{array}{l}\text { Diet composition of waterbirds foraging } \\
\text { in rice fields [51] }\end{array}$ & & \\
\hline & $\begin{array}{l}\text { Food consumption from waterbirds } \\
\text { (kJ/bird/day) in rice fields [51] }\end{array}$ & & \\
\hline & Microbial abundance (\%) [47] & & \\
\hline & Soil physical indicators [34] & & \\
\hline & Soil chemical indicators [34] & & \\
\hline & Soil biological indicators [34] & & \\
\hline & Nematode ecological indicators [34] & & \\
\hline & Plant species richness [33] & & \\
\hline & Bacteria species richness [33] & & \\
\hline & Fungi species richness [33] & & \\
\hline & $\begin{array}{l}\text { Mite species classification and } \\
\text { quantification [54] }\end{array}$ & & \\
\hline & Molecular microbial biomass [54] & & \\
\hline & Soil erosion ( $t /$ ha/year) [52] & & \\
\hline & $\begin{array}{l}\text { Plant species richness (Shannon } \\
\text { index) [30] }\end{array}$ & & \\
\hline & Soil loss (t/ha/year) [35] & & \\
\hline & Soil agronomic qualification index [39] & & \\
\hline & Risk of soil salinization [39] & & \\
\hline \multirow{7}{*}{ Habitat for Species } & $\begin{array}{c}\text { Functional dominance of Mediterranean } \\
\text { arable plants (Community weighted } \\
\text { mean) [48] }\end{array}$ & & $\begin{array}{l}\text { Willingness-to-pay of local } \\
\text { residents and tourist [24] }\end{array}$ \\
\hline & $\begin{array}{l}\text { Abundance and occurrence of a bird } \\
\text { species [35] }\end{array}$ & & $\begin{array}{l}\text { Cattle beef variable costs, } \\
\text { subsidies }(€ / \text { cow })[37]\end{array}$ \\
\hline & Weed species traits (\%) [41] & & $\begin{array}{c}\text { Gross Margin of beef cattle } \\
(€ / \text { cow })[37]\end{array}$ \\
\hline & Floristic composition of herbal layer [30] & & $\begin{array}{l}\text { Sheep meat variable costs, } \\
\text { subsidies ( } € \text { /ewe) [37] }\end{array}$ \\
\hline & Number of cattle and sheep holdings [37] & & $\begin{array}{c}\text { Gross Margin of sheep meat } \\
(€ / \text { ewe })[37]\end{array}$ \\
\hline & Number of cattle and sheep heads [37] & & \\
\hline & Drainage in wetland [39] & & \\
\hline \multirow{3}{*}{$\begin{array}{l}\text { Carbon } \\
\text { Sequestration and } \\
\text { Storage }\end{array}$} & Soil organic carbon (\%) [23] & & $\begin{array}{l}\text { Willingness-to-pay of local } \\
\text { residents and tourist [24] }\end{array}$ \\
\hline & Carbon sequestration (t/ha) [52] & & \\
\hline & Habitat index (\%) [52] & & \\
\hline \multirow{8}{*}{ Pest Control } & Soil arthropod abundance [55] & & \\
\hline & Soil arthropod functional diversity [55] & & \\
\hline & Bat passes (per minute) [56] & & \\
\hline & $\begin{array}{l}\text { DNA Extraction and sequencing of rice } \\
\text { borer (pest) from bat droppings [56] }\end{array}$ & & \\
\hline & Bat dropping collection [56] & & \\
\hline & $\begin{array}{l}\text { Morphological analysis of insect } \\
\text { fragments from bat droppings [56] }\end{array}$ & & \\
\hline & Bird species richness [36] & & \\
\hline & Bird species abundance [36] & & \\
\hline
\end{tabular}


Table A2. Cont.

\begin{tabular}{|c|c|c|c|}
\hline Ecosystem Service & Capacity & Flow & Benefit \\
\hline & Weed biomass $\left(\mathrm{g} / \mathrm{m}^{2}\right)$ [45] & & \\
\hline & Wheat leaf area $\left(\mathrm{mm}^{2} / \mathrm{mg}\right)[32]$ & & \\
\hline & Wheat mean Canopy height $(\mathrm{cm})$ [32] & & \\
\hline & Wheat seed mass (mg) [32] & & \\
\hline $\begin{array}{l}\text { Maintenance of } \\
\text { Genetic Diversity }\end{array}$ & Population of bearded vultures [46] & & \\
\hline $\begin{array}{l}\text { Local Climate and } \\
\text { Air Quality }\end{array}$ & & Climate regulation [31] & \\
\hline $\begin{array}{l}\text { Moderation of } \\
\text { Extreme Events }\end{array}$ & Number of fire events [46] & & \\
\hline \multirow{11}{*}{$\begin{array}{c}\text { Aesthetic } \\
\text { Appreciation and } \\
\text { Culture }\end{array}$} & $\begin{array}{l}\text { Number of habitats of community } \\
\text { importance [13] }\end{array}$ & $\begin{array}{l}\text { Preference Assessment } \\
\text { with locals (Frequency } \\
\text { of responses) [13] }\end{array}$ & $\begin{array}{l}\text { Willingness-to-pay of local } \\
\text { residents and tourist [24] }\end{array}$ \\
\hline & Floral richness [27] & & \\
\hline & Floral biological trait index [27] & & \\
\hline & Plot edge diversity [27] & & \\
\hline & Steinhaus index [27] & & \\
\hline & Plot spatial diversity [27] & & \\
\hline & Bird species richness [26] & & \\
\hline & Land-cover/topographic variables [26] & & \\
\hline & Vineyard management [26] & & \\
\hline & Shannon land-cover diversity index [26] & & \\
\hline & $\begin{array}{l}\text { Visual representation of agricultural } \\
\text { landscape [46] }\end{array}$ & & \\
\hline
\end{tabular}

\section{References}

1. Blondel, J. The 'Design' of Mediterranean Landscapes: A Millennial Story of Humans and Ecological Systems during the Historic Period. Hum. Ecol. 2006, 34, 713-729. [CrossRef]

2. Myers, N.; Mittermeier, R.A.; Mittermeier, C.G.; da Fonseca, G.A.B.; Kent, J. Biodiversity hotspots for conservation priorities. Nature 2000, 43, 853-858. [CrossRef]

3. Balzan, M.V.; Pinheiro, A.M.; Mascarenhas, A.; Morán-Ordóñez, A.; Ruiz-Frau, A.; Carvalho-Santos, C.; Vogiatzakis, I.; Arends, J.; Santana-Garcon, J.; Roces-Díaz, J.V.; et al. Improving ecosystem assessments in Mediterranean social-ecological systems: A DPSIR analysis. Ecosyst. People 2019, 15, 136-155. [CrossRef]

4. Martín-López, B.; Oteros-Rozas, E.; Cohen-Schacham, E.; Santos-Martín, F.; Nieto-Romero, M.; Carvalho-Santos, C.; González, J.A.; García-Llorente, M.; Klass, K.; Geijzendorffer, I.; et al. Ecosystem Services Supplied by the Mediterranean Basin Ecosystems. In Routledge Handbook of Ecosystem Services; Potschin, M., Haines-Young, R., Fish, R., Turner, R.K., Eds.; Routledge: London, UK; New York, NY, USA, 2016; pp. 405-414, ISBN 9781315775302.

5. Mace, G.M.; Norris, K.; Fitter, A.H. Biodiversity and ecosystem services: A multilayered relationship. Trends Ecol. Evol. 2012, 27, 19-26. [CrossRef]

6. Doblas-Miranda, E.; Alonso, R.; Arnan, X.; Bermejo, V.; Brotons, L.; de las Heras, J.; Estiarte, M.; Hódar, J.A.; Llorens, P.; Lloret, F.; et al. A review of the combination among global change factors in forests, shrublands and pastures of the Mediterranean Region: Beyond drought effects. Glob. Planet. Chang. 2017, 148, 42-54. [CrossRef]

7. Schröter, D.; Cramer, W.; Leemans, R.; Arnell, N.W.; Prentice, I.C.; Arau, M.B.; Bondeau, A.; Bugmann, H.; Carter, T.R.; Gracia, C.A.; et al. Ecosystem Service Supply and Vulnerability to Global Change in Europe. Science 2005, 1333-1337. [CrossRef] [PubMed]

8. García-Nieto, A.P.; Geijzendorffer, I.R.; Baró, F.; Roche, P.K.; Bondeau, A.; Cramer, W. Impacts of urbanization around Mediterranean cities: Changes in ecosystem service supply. Ecol. Indic. 2018, 91, 589-606. [CrossRef]

9. Malek, Ž.; Verburg, P.H.; Geijzendor, I.R.; Bondeau, A.; Cramer, W. Global change effects on land management in the Mediterranean region. Glob. Environ. Chang. 2018, 50, 238-254. [CrossRef] 
10. Holman, I.P.; Brown, C.; Janes, V.; Sandars, D. Can we be certain about future land use change in Europe? A multi-scenario, integrated-assessment analysis. Agric. Syst. 2017, 151, 126-135. [CrossRef]

11. Debolini, M.; Maraccini, E.; Dubeuf, J.P.; Geijzendorffer, I.R.; Guerra, C.; Simon, M.; Targetti, S.; Napoléone, C. Land and farming system dynamics and their drivers in the Mediterranean Basin. Land Use Policy 2018, 75, 702-710. [CrossRef]

12. Nieto-Romero, M.; Oteros-Rozas, E.; González, J.A.; Martín-López, B. Exploring the knowledge landscape of ecosystem services assessments in Mediterranean agroecosystems: Insights for future research. Environ. Sci. Policy 2014, 37, 121-133. [CrossRef]

13. Balzan, M.V.; Caruana, J.; Zammit, A. Assessing the capacity and flow of ecosystem services in multifunctional landscapes: Evidence of a rural-urban gradient in a Mediterranean small island state. Land Use Policy 2018, 75, 711-725. [CrossRef]

14. Baró, F.; Gómez-Baggethun, E.; Haase, D. Ecosystem service bundles along the urban-rural gradient: Insights for landscape planning and management. Ecosyst. Serv. 2017, 24, 147-159. [CrossRef]

15. Raudsepp-Hearne, C.; Peterson, G.D.; Bennett, E.M. Ecosystem service bundles for analyzing tradeoffs in diverse landscapes. Proc. Natl. Acad. Sci. USA 2010, 107, 5242-5247. [CrossRef] [PubMed]

16. Cole, L.J.; Kleijn, D.; Dicks, L.V.; Potts, S.G.; Albrecht, M.; Balzan, M.V.; Bartomeous, I.; Bebeli, P.J.; Bevk, D.; Biesmeijer, J.C.; et al. A critical analysis of the potential for EU Common Agricultural Policy measures to support wild pollinators on farmland. J. Appl. Ecol. 2020. [CrossRef] [PubMed]

17. Potschin, M.B.; Haines-Young, R.H. Ecosystem services: Exploring a geographical perspective. Prog. Phys. Geogr. 2011, 35, 575-594. [CrossRef]

18. De Groot, R.; Fisher, B.; Christie, M.; Aronson, J.; Braat, L.; Gowdy, J.; Haines-Young, R.; Maltby, E.; Neuville, A.; Polasky, S.; et al. Integrating the ecological and economic dimensions in biodiversity and ecosystem service valuation. In The Economics of Ecosystems and Biodiversity (TEEB): Ecological and Economic Foundations; Kumar, P., Ed.; Earthscan: London, UK; Washington, DC, USA, 2010.

19. Csardi, G.; Nepusz, T. The igraph software package for complex network research. InterJournal 2006, 1695, $1-9$.

20. Epskamp, S.; Cramer, A.; Waldrop, L.; Schittmann, V.; Borsboom, D. qgraph: Network Visualizations of Relationships in Psychometric Data. J. Stat. Softw. 2012, 48, 1-18. [CrossRef]

21. R Core Team. R: A Language and Environment for Statistical Computing; R Foundation for Statistical Computing: Vienna, Austria, 2020.

22. Villamagna, A.M.; Angermeier, P.L.; Bennett, E.M. Capacity, pressure, demand, and flow: A conceptual framework for analyzing ecosystem service provision and delivery. Ecol. Complex. 2013, 15, 114-121. [CrossRef]

23. Montanaro, G.; Xiloyannis, C.; Nuzzo, V.; Dichio, B. Orchard management, soil organic carbon and ecosystem services in Mediterranean fruit tree crops. Sci. Hortic. 2017, 217, 92-101. [CrossRef]

24. Soy-Massoni, E.; Langemeyer, J.; Varga, D.; Sáez, M.; Pintó, J. The importance of ecosystem services in coastal agricultural landscapes: Case study from the Costa Brava, Catalonia. Ecosyst. Serv. 2016, 17, 43-52. [CrossRef]

25. Schaller, L.; Targetti, S.; Villanueva, A.J.; Zasada, I.; Kantelhardt, J.; Arriaza, M.; Bal, T.; Giray, F.H.; Majewski, E.; Malak-rawlikowska, A.; et al. Agricultural landscapes, ecosystem services and regional competiveness-Assessing drivers and mechanisms in nine European case study areas. Land Use Policy 2018, 1-11. [CrossRef]

26. Assandri, G.; Bogliani, G.; Pedrini, P.; Brambilla, M. Beautiful agricultural landscapes promote cultural ecosystem services and biodiversity conservation. Agric. Ecosyst. Environ. 2018, 256, 200-210. [CrossRef]

27. Cohen, M.; Bilodeau, C.; Alexandre, F.; Godron, M.; Andrieu, J.; Grésillon, E.; Garlatti, F.; Morganti, A. What is the plant biodiversity in a cultural landscape? A comparative, multi-scale and interdisciplinary study in olive groves and vineyards (Mediterranean France). Agric. Ecosyst. Environ. 2015, 212, 175-186. [CrossRef]

28. Bernués, A.; Tello-García, E.; Rodríguez-Ortega, T.; Ripoll-Bosch, R. Agricultural practices, ecosystem services and sustainability in High Nature Value farmland: Unraveling the perceptions of farmers and nonfarmers. Land Use Policy 2016. [CrossRef]

29. Torralba, M.; Fagerholm, N.; Burgess, P.J.; Moreno, G.; Plieninger, T. Do European agroforestry systems enhance biodiversity and ecosystem services? A meta-analysis. Agric. Ecosyst. Environ. 2016, 230, 150-161. [CrossRef] 
30. López-Sánchez, A.; San Miguel, A.; López-Carrasco, C.; Huntsinger, L.; Roig, S. The important role of scattered trees on the herbaceous diversity of a grazed Mediterranean dehesa. Acta Oecologica 2016. [CrossRef]

31. Willaarts, B.A.; Volk, M.; Aguilera, P.A. Assessing the ecosystem services supplied by freshwater flows in Mediterranean agroecosystems. Agric. Water Manag. 2012, 105, 21-31. [CrossRef]

32. Guerrero, I.; Carmona, C.P.; Morales, M.B.; Oñate, J.J.; Peco, B. Non-linear responses of functional diversity and redundancy to agricultural intensification at the field scale in Mediterranean arable plant communities. Agric. Ecosyst. Environ. 2014, 195, 36-43. [CrossRef]

33. Castro, H.; Barrico, L.; Rodríguez-Echeverría, S.; Freitas, H. Trends in plant and soil microbial diversity associated with Mediterranean extensive cereal-fallow rotation agro-ecosystems. Agric. Ecosyst. Environ. 2016, 217, 33-40. [CrossRef]

34. Salomé, C.; Coll, P.; Lardo, E.; Metay, A.; Villenave, C.; Marsden, C.; Blanchart, E.; Hinsinger, P.; Le Cadre, E. The soil quality concept as a framework to assess management practices in vulnerable agroecosystems: A case study in Mediterranean vineyards. Ecol. Indic. 2016, 61, 456-465. [CrossRef]

35. Brambilla, M.; Ilahiane, L.; Assandri, G.; Ronchi, S.; Bogliani, G. Combining habitat requirements of endemic bird species and other ecosystem services may synergistically enhance conservation efforts. Sci. Total Environ. 2017, 586, 206-214. [CrossRef] [PubMed]

36. De Frutos, A.; Olea, P.P.; Mateo-Tomás, P. Responses of medium- and large-sized bird diversity to irrigation in dry cereal agroecosystems across spatial scales. Agric. Ecosyst. Environ. 2015, 207, 141-152. [CrossRef]

37. Bernués, A.; Ruiz, R.; Olaizola, A.; Villalba, D.; Casasús, I. Sustainability of pasture-based livestock farming systems in the European Mediterranean context: Synergies and trade-offs. Livest. Sci. 2011, 139, 44-57. [CrossRef]

38. Santana-Cordero, A.M.; Ariza, E.; Romagosa, F. Studying the historical evolution of ecosystem services to inform management policies for developed shorelines. Environ. Sci. Policy 2016, 64, 18-29. [CrossRef]

39. Trolard, F.; Bourrié, G.; Baillieux, A.; Buis, S.; Chanzy, A.; Clastre, P.; Closet, J.F.; Courault, D.; Dangeard, M.L.; Di Virgilio, N.; et al. The PRECOS framework: Measuring the impacts of the global changes on soils, water, agriculture on territories to better anticipate the future. J. Environ. Manag. 2016. [CrossRef] [PubMed]

40. Malek, Ž.; Verburg, P.H. Adaptation of land management in the Mediterranean under scenarios of irrigation water use and availability. Mitig. Adapt. Strateg. Glob. Chang. 2017, 23, 821-837. [CrossRef]

41. Juárez-Escario, A.; Conesa, J.A.; Solé-Senan, X.O. Management as a driver of functional patterns and alien species prominence in weed communities of irrigated orchards in Mediterranean areas. Agric. Ecosyst. Environ. 2017. [CrossRef]

42. Potts, S.G.; Petanidou, T.; Roberts, S.; O’Toole, C.; Hulbert, A.; Willmer, P. Plant-pollinator biodiversity and pollination services in a complex Mediterranean landscape. Biol. Conserv. 2006, 129, 519-529. [CrossRef]

43. Castro, A.J.; Martinlopez, B.; Garciallorente, M.; Aguilera, P.A.; Lopez, E.; Cabello, J. Social preferences regarding the delivery of ecosystem services in a semiarid Mediterranean region. J. Arid Environ. 2011, 75, 1201-1208. [CrossRef]

44. Martínez-Sastre, R.; Ravera, F.; González, J.A.; López Santiago, C.; Bidegain, I.; Munda, G. Mediterranean landscapes under change: Combining social multicriteria evaluation and the ecosystem services framework for land use planning. Land Use Policy 2017, 67, 472-486. [CrossRef]

45. Lazzaro, M.; Costanzo, A.; Bàrberi, P. Single vs multiple agroecosystem services provided by common wheat cultivar mixtures: Weed suppression, grain yield and quality. Firld Crops Res. 2017, 221, 277-297. [CrossRef]

46. Rodríguez-Ortega, T.; Bernués, A.; Alfnes, F. Psychographic profile affects willingness to pay for ecosystem services provided by Mediterranean high nature value farmland. Ecol. Econ. 2016, 128, 232-245. [CrossRef]

47. Griffiths, B.S.; Römbke, J.; Schmelz, R.M.; Scheffczyk, A.; Faber, J.H.; Bloem, J.; Pérès, G.; Cluzeau, D.; Chabbi, A.; Suhadolc, M.; et al. Selecting cost effective and policy-relevant biological indicators for European monitoring of soil biodiversity and ecosystem function. Ecol. Indic. 2016. [CrossRef]

48. Solé-Senan, X.O.; Juárez-Escario, A.; Robleño, I.; Conesa, J.A.; Recasens, J. Using the response-effect trait framework to disentangle the effects of agricultural intensification on the provision of ecosystem services by Mediterranean arable plants. Agric. Ecosyst. Environ. 2017, 247, 255-264. [CrossRef]

49. Mendoza-García, M.; Blanco-Moreno, J.M.; Chamorro, L.; José-María, L.; Sans, F.X. Patterns of flower visitor abundance and fruit set in a highly intensified cereal cropping system in a Mediterranean landscape. Agric. Ecosyst. Environ. 2018, 254, 255-263. [CrossRef] 
50. Creamer, R.E.; Hannula, S.E.; Leeuwen, J.P.V.; Stone, D.; Rutgers, M.; Schmelz, R.M.; Ruiter, P.C.D.; Hendriksen, N.B.; Bolger, T.; Bouffaud, M.L.; et al. Ecological network analysis reveals the inter-connection between soil biodiversity and ecosystem function as affected by land use across Europe. Appl. Soil Ecol. 2016. [CrossRef]

51. Navedo, J.G.; Hahn, S.; Parejo, M.; Abad-Gómez, J.M.; Gutiérrez, J.S.; Villegas, A.; Sánchez-Guzmán, J.M.; Masero, J.A. Unravelling trophic subsidies of agroecosystems for biodiversity conservation: Food consumption and nutrient recycling by waterbirds in Mediterranean rice fields. Sci. Total Environ. 2015, 511, 288-297. [CrossRef]

52. Palma, J.H.N.; Graves, A.R.; Bunce, R.G.H.; Burgess, P.J.; de Filippi, R.; Keesman, K.J.; van Keulen, H.; Liagre, F.; Mayus, M.; Moreno, G.; et al. Modeling environmental benefits of silvoarable agroforestry in Europe. Agric. Ecosyst. Environ. 2007, 119, 320-334. [CrossRef]

53. Rossetti, I.; Bagella, S.; Cappai, C.; Caria, M.C.; Lai, R.; Roggero, P.P.; Martins da Silva, P.; Sousa, J.P.; Querner, P.; Seddaiu, G. Isolated cork oak trees affect soil properties and biodiversity in a Mediterranean wooded grassland. Agric. Ecosyst. Environ. 2015, 202. [CrossRef]

54. Dirilgen, T.; Arroyo, J.; Dimmers, W.J.; Faber, J.; Stone, D.; Martins da Silva, P.; Carvalho, F.; Schmelz, R.; Griffiths, B.S.; Francisco, R.; et al. Mite community composition across a European transect and its relationships to variation in other components of soil biodiversity. Appl. Soil Ecol. 2016. [CrossRef]

55. Gkisakis, V.; Volakakis, N.; Kollaros, D.; Bàrberi, P.; Kabourakis, E.M. Soil arthropod community in the olive agroecosystem: Determined by environment and farming practices in different management systems and agroecological zones. Agric. Ecosyst. Environ. 2016, 218, 178-189. [CrossRef]

56. Puig-Montserrat, X.; Torre, I.; López-Baucells, A.; Guerrieri, E.; Monti, M.M.; Ràfols-García, R.; Ferrer, X.; Gisbert, D.; Flaquer, C. Pest control service provided by bats in Mediterranean rice paddies: Linking agroecosystems structure to ecological functions. Mamm. Biol. 2015. [CrossRef]

(C) 2020 by the authors. Licensee MDPI, Basel, Switzerland. This article is an open access article distributed under the terms and conditions of the Creative Commons Attribution (CC BY) license (http://creativecommons.org/licenses/by/4.0/). 